\title{
マルチカスプ磁場閉じ込め表面波プラズマ源
}

\begin{tabular}{|c|c|c|c|c|c|}
\hline 非会員 & 津 & 田 & & 睦 & (三菱電機) \\
\hline 正 員 & 荦 & & 高 & 一 & (三菱電機) \\
\hline 正 員 & 土 & 橋 & 祐 & 亮 & (三菱電機) \\
\hline 正 員 & 花 & 崎 & & 稔 & (三菱電機) \\
\hline 非会員 & 米 & 村 & 俊 & 雄 & (三菱電機) \\
\hline
\end{tabular}

\section{A Surface-Wave Plasma Source with Magnetic Multicusp Fields}

Mutumi Tuda, Non-member, Kouichi Ono, Member, Masaaki Tsuchihashi, Member, Minoru Hanazaki, Member, Toshio Komemura, Non-member (Mitsubishi Electric Corporation)

A new-type microwave plasma source has been developed for materials processing. The plasma reactor employed a launcher of azimuthally symmetric surface waves at a frequency of $2.45 \mathrm{GHz}$ and also magnetic multicusp fields around the reactor chamber walls. This configuration yielded high-density $\left(N_{e} \geq 10^{11} \mathrm{~cm}^{-3}\right)$ plasmas sustained by surface waves even at low gas pressures below $10 \mathrm{mT}$ orr, following easy plasma ignition by electron cyclotron resonance (ECR) discharges. Electrical and optical diagnostics were made to obtain the plasma properties in Ar. It was shown that a transition from ECR excited to surface-wave excited plasmas occurs under conditions where the plasma electron density exceeds a critical value of $N_{e} \sim 1 \times 10^{11} \mathrm{~cm}^{-3}$.

キーワード：マイクロ波プラズマ, 表面波プラズマ, マルチカスプ磁場, 電子サイクロトロン共鳴, プラズマプロセス

\section{1.はじめに}

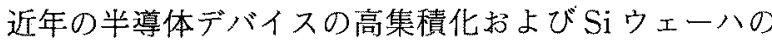
大面積化に伴い, 半導体表面の微細加工技術において, 低 気圧・高密度プラズマ(プラズマ密度 $N_{e} \geq 10^{11} \mathrm{~cm}^{-3}$, 動 作ガス圧力 $P_{0} \leq 10 \mathrm{~m}$ Torr) を大口径に生成できるプラズ マ源が求められている。このような低気圧・高密度プラズ マ源として, ECR (Electron Cyclotron Resonance), Helicon, ICP (Inductively Coupled Plasma) などが今ま でに研究・開発されてきた(1)。更に, 最近では, NLD (Neutral-Loop Discharge) (2) やUHF (Ultrahigh Frequency) (3) などの新しいプラズマ源の探索も盛んに行 われている。

表面波プラズマ（SWP：Surface-Wave Plasma）は, 電極や外部磁場を必要とせず，しかもマイクロ波のカット オフがないことから, 半導体プロセスに用いられる高密度 プラズマ源に適していると考えられる(1)(4)。また，その大 口径化に関しては，テフロンシートやスロットなどを用い た平面アンテナにより表面波を励起・伝搬させ, 直径 30 $\mathrm{cm}$ 程度の大口径表面波プラズマの生成も実現されてい る(5) (9)。しかしながら，現状の表面波プラズマ源では， 低ガス圧力領域（ $P_{0} \leq 10 \mathrm{~m}$ Torr）において放電の開始や 維持が困難なため，その用途は比較的高気圧で用いられる
アッシングや酸化膜エッチングなどに限られる。このた め, 低ガス圧力領域でも安定に動作し, 微細加工にも広く 用いられることができる表面波プラズマ源が強く望まれて いる。

リアクタの壁近傍に形成されるマルチカスプ磁場は，プ ラズマ中の電子の閉じ込めやプラズマの均一性向上に効果 があることが知られており(10) (12), 熱陰極方式のバケット 型プラズマイオン源では，このマルチカスプ磁場が広く用 いられている。また，最近では希土類や $\mathrm{Nd}-\mathrm{Fe}-\mathrm{B}$ 系の高 い残留磁束密度を有する永久磁石を用いて，リアク夕の内 壁近傍に ECR 共鳴に必要な磁場強度（例えば, 周波数 $2.45 \mathrm{GHz}$ のマイクロ波に対して磁場強度 $B=875 \mathrm{G}$ ) も 同時に発生するコンパクトなマルチカスプ磁場型 ECR プ ラズマ源の開発も行われてきた(13) 〜18)。しかしながら，こ のような ECR プラズマ源では, 壁近傍の共鳴磁場領域 (B〜875G) で主にプラズマの生成が行われるため，壁へ のプラズマの損失が比較的大きく，プラズマの生成効率が 期待されるほど良くない。

著者らは, 半導体表面の微細加工やクリーニングなどに 応用することを目的として，従来の表面波プラズマ源では 動作困難であった低ガス圧力領域でも高密度なプラズマの 生成を実現するために，軸対称モードの表面波励起とマル チカスプ磁場によるプラズマ閉じ込めを組み合わせた新し 
いプラズマ源の開発を進めている。本方式の表面波プラズ マ源では,リアクタの内壁近傍に共鳴磁場も同時に存在す るので，プラズマの点火には ECR 放電を利用することが できる。更に，プラズマが発生した後には，マルチカスプ 磁場内の無磁場領域において表面波励起により高密度なプ ラズマの生成が行われると同時に, 磁場閉じ込めの効果に よりプラズマの壁への拡散が効果的に抑えられる。こうし て, 本方式のプラズマ源では, 低ガス圧力領域でも安定 に，かつ高効率に高密度プラズマを生成することが可能で あると期待される。本論文では，このマルチカスフ磁場閉 じ込め表面波プラズマ源の装置構成および生成されたプラ ズマの特性について述べる。

\section{2. 実験装置 - 方法}

図 1 に, 表面波プラズマ装置の構成と各種プラズマ計測 の実験配置を示す。プラズマ装置は，ステンレス鋼製のプ ラズマ生成室 (内径 $15 \mathrm{~cm}$, 長さ $20 \mathrm{~cm}$ ) と真空排気系を 備えた処理室からなる。プラズマ生成室の側壁は複数の計 測ポートを有し, 放電ガスの導入や各種プラズマ計測が行 える。また, 処理窒底面には直径 $15 \mathrm{~cm}$ の石英空が設け られ，プラズマ発光の観察や径方向分布が測定できるよう になっている。

フラズマ生成室の中心軸上には表面波を励起・伝搬させ るアンテナが設置されている。このアンテナは, 試験管状 の石英チューブ（外径 $2 \mathrm{~cm}$, 長さ $10 \mathrm{~cm}$ ) と空冷された

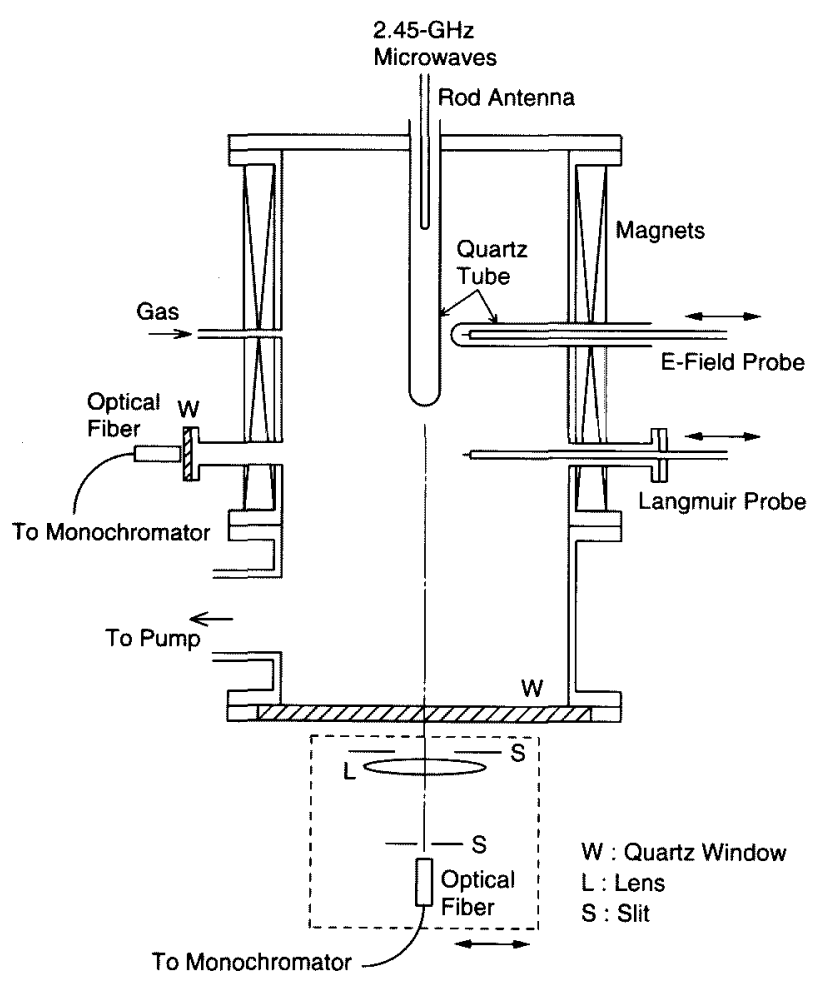

図 1 実験装置および配置図

Fig. 1. Experimental apparatus and setup used in this study.
ロッドアンテナ（直径 $5 \mathrm{~mm}$ ) から構成され, 方形導波管 より同軸モードに変換された周波数 $2.45 \mathrm{GHz}$ のマイクロ 波電力がロッドアンテナに供給される。このロッドアンテ ナから放射されたマイクロ波は，石英チューブ壁（厚み 2 $\mathrm{mm}$ )を介してプラズマ生成室内に導入されるが，このよ うなアンテナ配置では, 軸対称モードの表面波が石英チュ ーブとプラズマとの境界に沿って伝搬することが知られて いる(19) -(21)。

プラズマ生成室の周囲には $\mathrm{Sm}-\mathrm{Co}$ の永久磁石 $(2 \times 2$ $\mathrm{cm}$ 角棒）を用いて 12 極のラインカスプ磁場が形成され ている。磁場強度分布の計算結果を図 2 に示す。磁場強度 は, 生成室の内壁表面上（半径 $7.5 \mathrm{~cm}$ ) で $B=1.5 \sim 3$ $\mathrm{kG}$ であり, 生成室の中心に向かって急速に減少する。半 径約 $6 \mathrm{~cm}$ の位置に ECR 共鳴領域 $(B=875 \mathrm{G})$ が存在 し, また, 上述の表面波励起アンテナを設置している生成 室の中心部では, 半径約 $2.5 \mathrm{~cm}$ にわたって無磁場領域 $(B \lesssim 10 \mathrm{G})$ が形成されている。

生成されたプラズマの評価には, 図 1 に示すように, フ ローブ測定, 発光分光およびマイクロ波電場測定を用い た。プラズマ生成室の計測ポートから円筒型 Langmuir プローブ（W 探針, 直径 $0.5 \mathrm{~mm}$, 長さ $3 \mathrm{~mm}$ ) をプラズ マ中心に㨉入し，プラズマ密度・電子温度などの径方向分 布を測定した。ここで,プロープの軸方向位置は石英チュ ーブ端の約 $2 \mathrm{~cm}$ 下流である。また, プローブ測定と同じ 軸方向位置において, 石英空からプラズマ発光を光ファイ バを通じて焦点距離 $30 \mathrm{~cm}$ の分光器に集光し, 径方向に 積分された $\mathrm{Ar}$ (波長 $750.3 \mathrm{~nm}$ )および $\mathrm{Ar}^{+}(488.0$

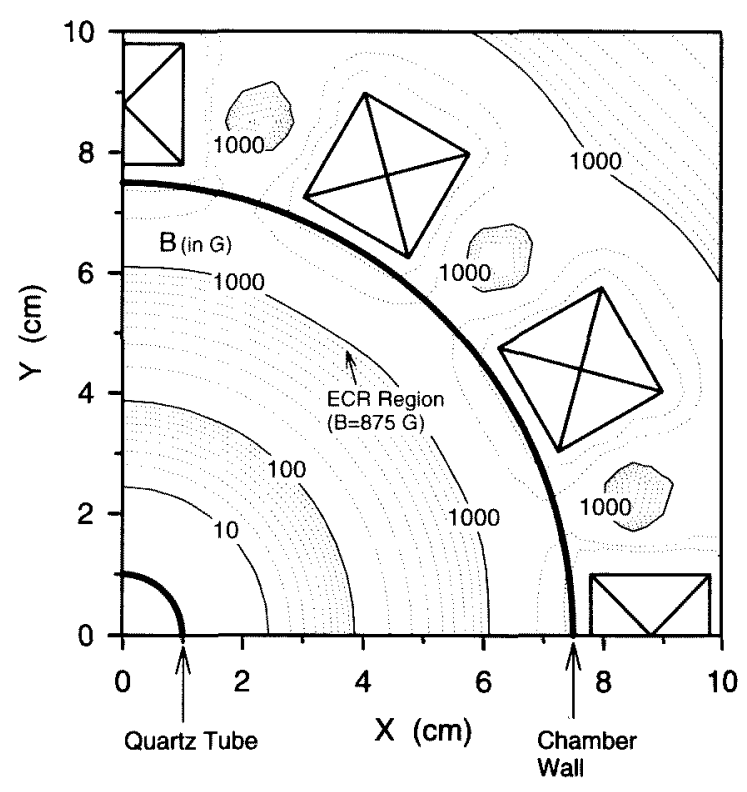

図 2 磁場強度分布

Fig. 2. Calculated magnetic-field intensity contour map; the microwave launcher is located in the field-free region $(B \leqslant 10 \mathrm{G})$, and the ECR resonance region $(B=875 \mathrm{G})$ is seen at a radius of $r \approx 6 \mathrm{~cm}$ near the wall surface $(r=7.5 \mathrm{~cm})$. 
$\mathrm{nm} ）$ の発光ライン強度を測定した。一方，これらの発光 強度の径方向分布の測定は処理室底面の石英空からスリッ ト, レンズ, 光ファイバからなる光学系を径方向に移動さ せることにより行った。更に，プラズマ生成室の計测ポー トから試験管状の石英チューブ（外径 $6 \mathrm{~mm}$ ) をプラズマ 中に㨀入し, 先端部を約 $2 \mathrm{~mm}$ 露出させたセミリジッ ド・ケーブル $(50 \Omega$, 外径約 $2 \mathrm{~mm})$ をこのチューブ内で 移動させてプラズマ中のマイクロ波電場強度の径方向分布 を測定した。

本実験では，放電ガスとして Arを用い，ガス圧力 $P_{0}=$ $0.1 \sim 10 \mathrm{mTorr}$, 入射マイクロ波電力 $P_{\mathrm{n}}=20 \sim 500 \mathrm{~W}$ の 範囲で生成された Arプラズマ特性を調べた。なお, す心゙ てのプラズマ生成条件に扔いて，マイクロ波整合器のスタ ブ位置を調整することによりマイクロ波の反射電力は入射 電力の $10 \%$ 以下であった。

\section{3. 実験結果および考察}

〈3.1〉 プラズマ点火特性 図 3 に, Ar ガス圧力 0.1 から $10 \mathrm{~m}$ Torr の範囲に扔いて, 放電開始に要する最小マ イクロ波電力を示す。ガス圧力の減少に伴い, 放電の開始 に必要となるマイク口波電力は増加するが, 本方式では 〜10-4Torr の低ガス圧力下でも数百 W の比較的低電力で プラズマが点火・発生できることが分かる。これは，プラ ズマ生成室の内壁近傍に存在する共鳴磁場領域で ECR 放 電によりプラズマの点火が起こるためと考えられる。

〈3・2〉 電子軌道計算 マルチカスプ磁場におけるプ ラズマの閉じ込め効果を調ベるために，プラズマ生成室内 の電子軌道をモンテカルロ法を用いてシミュレートした。 電子の発生は, 生成室中央（軸方向位置 $z=10 \mathrm{~cm}$ ）に仮 想配置した半径 $1 \mathrm{~cm}$ の円環上（磁場強度は $10 \mathrm{G}$ 以内） と半径 $5 \mathrm{~cm}$ の円環上（磁場強度は約 $400 \mathrm{G}$ ）の二つの場 合について計算を行った。ここでは, 簡単のためにプラズ

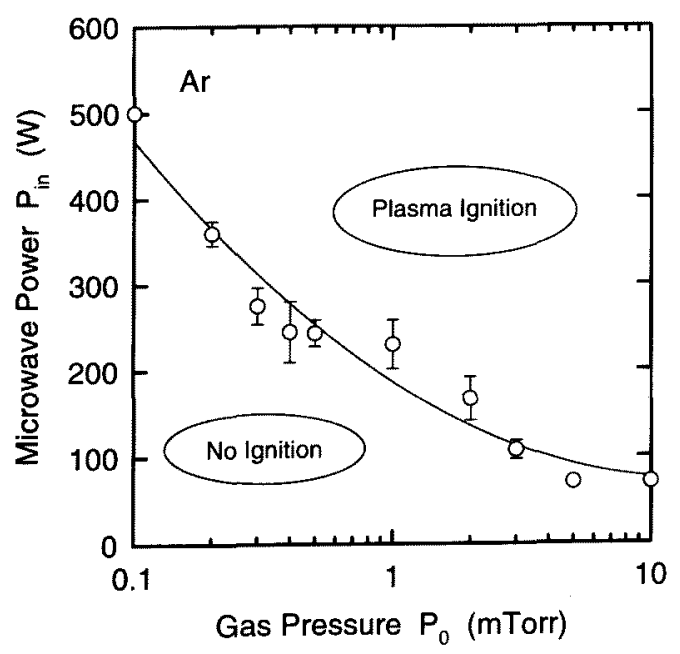

図 3 プラズマ点火特性

Fig. 3. Minimum microwave power $P_{\text {in }}$ for plasma ignition as a function of Ar gas pressure $P_{0}$.
マやシース内の電場の存在やガス粒子との衝突の効果は無 視した。また，電子の初期速度 $\left(V_{x 0}, V_{y 0}, V_{z 0}\right)$ は電子温 度 $5 \mathrm{eV}$ の Maxwell 分布に従うと仮定し, 電子を半径方 向にのみ放出させた $\left(V_{z 0}=0\right)$ 。なお，計算に用いた粒子 数はともに $N=20$ である。得られた結果を図 4 に示す。 半径 $1 \mathrm{~cm}$ の円環上で発生した電子の運動は, 磁場のカス プ点を除くと無磁場領域内（半径 $r \leqq 3 \mathrm{~cm}$ ) に制限され ており，効果的にプラズマ生成室内に閉じ込められている のが分かる。一方, 磁場強度が大きく, しかも磁場こう配 の強い半径 $5 \mathrm{~cm}$ の円環上で発生した電子は, $\mathrm{grad}-B$ あ るいは湾曲ドリフトの影響を受け, 生成室の軸方向にドリ フト運動している。この検討から分加るように, 無磁場領 域にアンテナを設置する本方式の表面波プラズマ源は, マ ルチカスフ磁場の閉じ込め効果が強く働く。一方, マルチ カスプ磁場を用いた ECR プラズマ源(13) (18)では, 電子の 発生場所が共鳴磁場領域（ $B \sim 875 \mathrm{G} ）$ であるためにドリ フトの影響を強く受け，電子の閉じ込め効果が弱い。

〈3・3〉 マイクロ波電力依存性図5 図8に, ガス 生力を $2 \mathrm{mT}$ Torr に固定し, マイクロ波電力を 20 から 500 Wまで変化させた際のプラズマ特性の変化を示す。

図 5 と図 6 は，それぞれマイクロ波電力をパラメー夕 $\left(P_{\mathrm{ln}}=20,50,300 \mathrm{~W}\right)$ として, 処理室底面の石英空から見 たプラズマ発光の写真と Ar（750.3 nm）の発光強度の径 方向分布である。マイクロ波電力が $20 \mathrm{~W}$ の場合には, プ

(a) Electron Source: $R=1 \mathrm{~cm}(B \leq 10 \mathrm{G}), Z=10 \mathrm{~cm}$
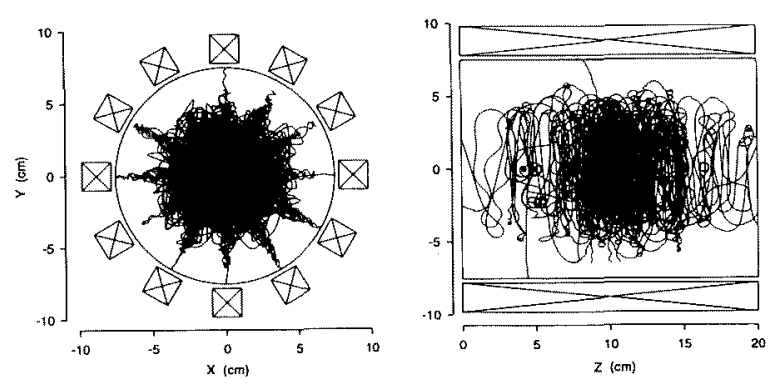

(b) Electron Source : $R=5 \mathrm{~cm}(B \approx 400 \mathrm{G}), Z=10 \mathrm{~cm}$
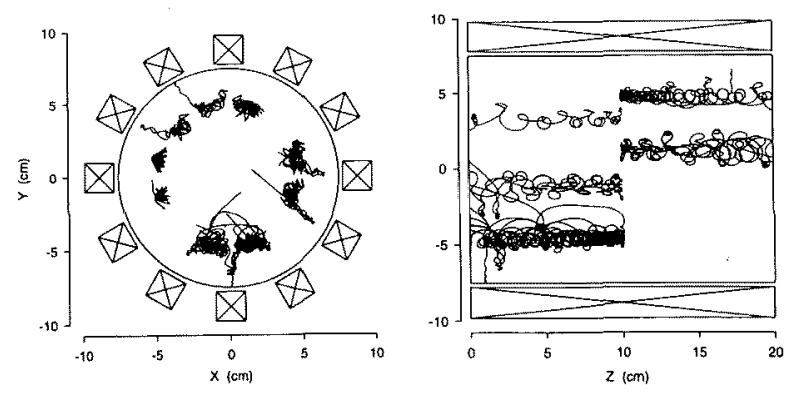

図 4 マルチカスプ磁場中の電子軌道 Fig. 4. Calculated electron trajectories in the magnetic multicusp fields; electrons are initially generated at radii of $(a) r=1 \mathrm{~cm}(B \leqslant 10 \mathrm{G})$ and $(\mathrm{b}) r$ $=5 \mathrm{~cm}(B \approx 400 \mathrm{G})$. 


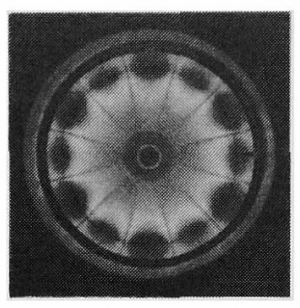

(a) $20 \mathrm{~W}$

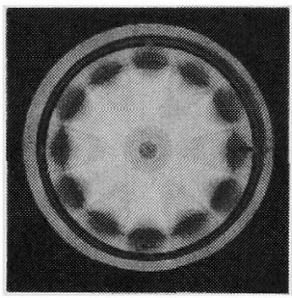

(b) $50 \mathrm{~W}$

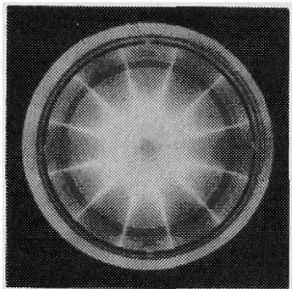

(c) $300 \mathrm{~W}$

図 5 プラズマ発光分布（マイクロ波電力 依存性)

Fig. 5. Bottom views of the discharge for different microwave powers $P_{\mathrm{in}}$ at $P_{0}=2 \mathrm{mTorr}$; (a) $P_{\mathrm{in}}=20$ $\mathrm{W}$; (b) $P_{\mathrm{in}}=50 \mathrm{~W}$; and (c) $P_{\mathrm{in}}=300 \mathrm{~W}$.

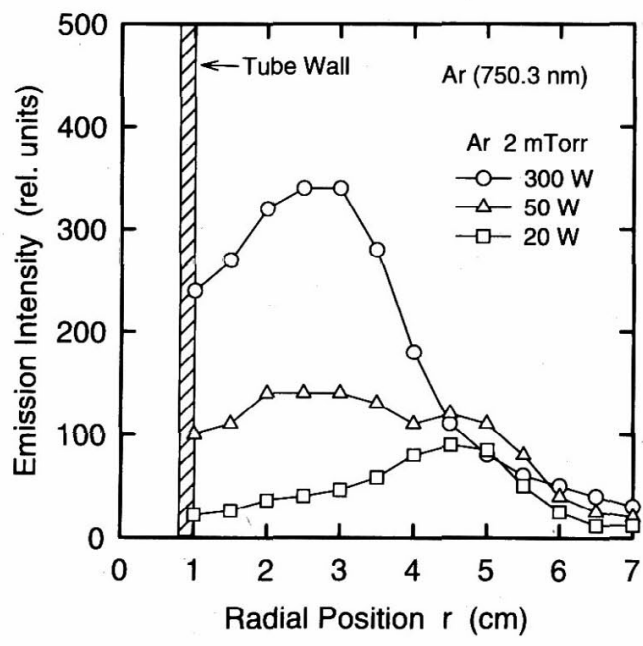

図 6 Ar 発光強度の径方向分布（マイクロ波 電力依存性)

Fig. 6. Radial distributions of the $750.3 \mathrm{~nm}$ Ar emission intensity for different microwave powers $P_{\text {in }}$ at $P_{0}=2$ mTorr.

ラズマ生成室の周辺部で弱いプラズマの発光が見られる が, このときの Ar の発光強度は ECR 共鳴領域に近い半 径 $r \approx 5 \mathrm{~cm}$ の位置でピークを示していることが分かる。 マイクロ波電力を増加させると，まず生成室全体に発光領
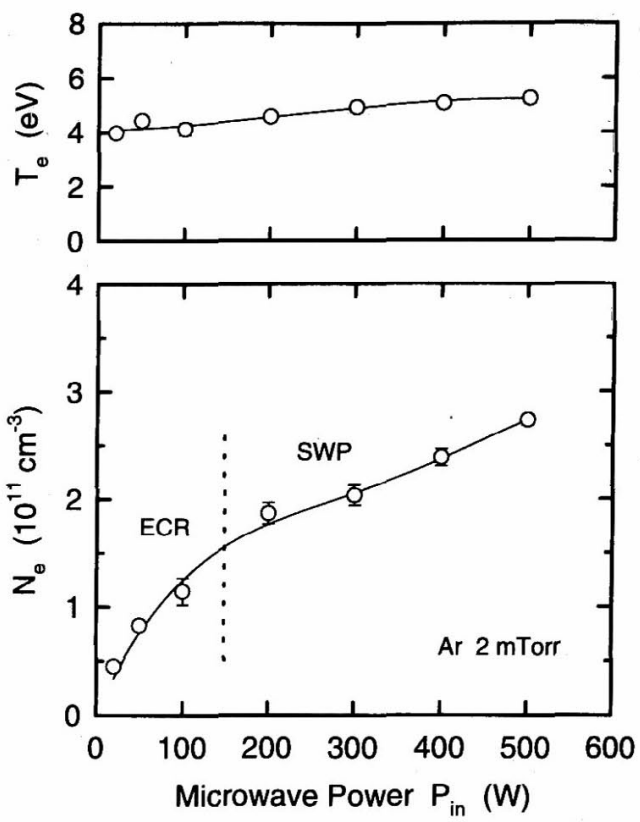

図 7 プラズマ密度 $\left(N_{e}\right)$ および電子温度 $\left(T_{e}\right)$ のマイクロ波電力依存性

Fig. 7. Plasma density $N_{e}$ and electron temperature $T_{e}$ as a function of microwave power $P_{\mathrm{in}}$ at $P_{0}$ $=2 \mathrm{~m}$ Torr.

域が広がる。更に電力が $200 \mathrm{~W}$ 以上になると, 生成室の 中心軸上に設置された石英チュープの近傍にのみ強いプラ ズマ発光が見られるようになる。これに対応して, Arの 発光強度のピークも半径 $r \approx 3 \mathrm{~cm}$ の位置に移動し, 生成 室の周辺部 $(r \gtrsim 5 \mathrm{~cm})$ では発光強度が著しく小さくなっ ているのが分かる。

このようなプラズマ発光分布の大きな変化は, マイクロ 波電力を増加させると, 放電の形態が共鳴磁場領域で主に プラズマを生成する ECR 励起から石英チューブの近傍で プラズマを生成する表面波励起に変化したためと考えられ る。

図 7 に, プローブ先端位置をプラズマ生成室の中心 $(r$ $=0)$ に固定し, プラズマ密度 $\left(N_{e}\right)$ と電子温度 $\left(T_{e}\right)$ を 調べた結果を示す。ここで, プローブの軸方向位置は石英 チューブ端の約 $2 \mathrm{~cm}$ 下流である。なお, プローブ法によ りプラズマ密度を求める際には, 得られたイオン飽和電流 と電子温度から見積もった。図から分かるように, マイク ロ波電力の増加に伴ってプラズマ密度は単調に増加し, 実 験の範囲内ではプラズマ密度の飽和は見られなかった。得 られたプラズマ密度は, マイクロ波電力 $500 \mathrm{~W}$ のをに 最大 $N_{e} \approx 2.8 \times 10^{11} \mathrm{~cm}^{-3}$ であり，この值はマイクロ波のカ ットオフ密度 $\left(N_{c} \sim 7 \times 10^{10} \mathrm{~cm}^{-3}\right)$ の約 4 倍の值である。 一方, プラズマ中の電子温度は, マイクロ波電力を増加さ せると, $T_{e} \approx 4$ から $5 \mathrm{eV}$ へとわずかに増加するのみであ った。

図 8 に, プローブ測定と同じ軸方向位置における径方向 に積分された $\mathrm{Ar}(750.3 \mathrm{~nm})$ と $\mathrm{Ar}^{+}(488.0 \mathrm{~nm})$ の発光 


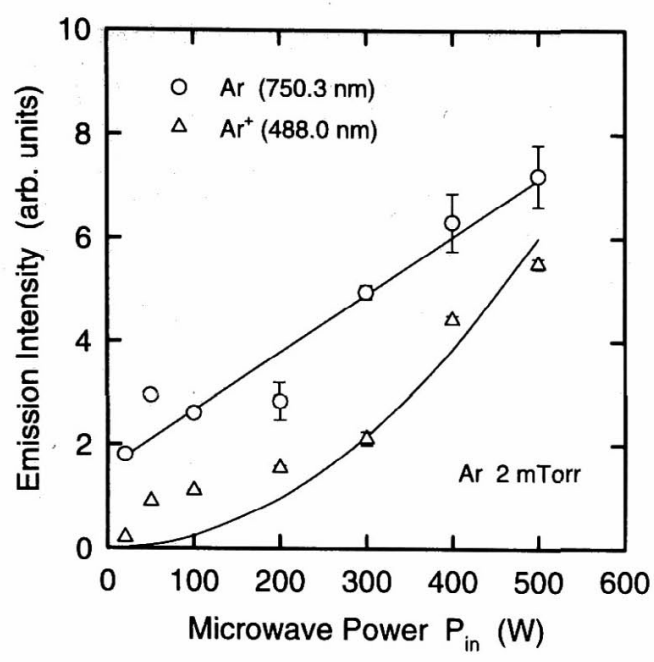

図 $8 \mathrm{Ar}$ および $\mathrm{Ar}^{+}$発光強度のマイクロ波 電力依存性

Fig. 8. Radially integrated intensities of the 750.3 $\mathrm{nm} \mathrm{Ar}$ and $488.0 \mathrm{~nm} \mathrm{Ar}^{+}$emissions as a function of microwave power $P_{\text {in }}$ at $P_{0}=2 \mathrm{~m}$ Torr.

強度のマイクロ波電力依存性を示す。な抢, 図中の直・曲 線は, $\mathrm{Ar}$ のデー夕に対して一次関数で, $\mathrm{Ar}^{+}$のデー夕に 対して二次関数でフィッティングすることにより求めたも のである。図に示されるように, $\mathrm{Ar}(750.3 \mathrm{~nm})$ の発光 強度はマイクロ波電力に対してほほ直線的に増加し, $\mathrm{Ar}^{+}$ $(488.0 \mathrm{~nm})$ の発光強度はだいたい二次関数的に増加して いると言える。これらのことから， $\mathrm{Ar}$ 打よび $\mathrm{Ar}^{+}$の発光 強度はそれぞれ

$$
\begin{aligned}
& I_{\mathrm{Ar}}=k_{\mathrm{Ar}} N_{g} N_{e}, \\
& I_{\mathrm{Ar}+}=k_{\mathrm{Ar}+} N_{i} N_{e} \approx k_{\mathrm{Ar}}+N_{e}^{2},
\end{aligned}
$$

に従い，マイクロ波電力の増加とともに，プラズマ密度 $N_{e}$ は飽和することなく直線的に増加していると言える。 ここで, $k_{\mathrm{Ar}}$ と $k_{\mathrm{Ar}}$ はそれぞれ $\mathrm{Ar}$ と $\mathrm{Ar}^{+}$の発光励起定数, $N_{g}$ と $N_{i}$ は, それぞれ $\mathrm{Ar}$ ガス密度とイオン密度である。 得られた結果は, 図 7 に示すプローブによるプラズマ密度 測定の結果に矛盾しない。

このようなプローブ計測および発光分光の結果から, 本 方式のプラズマ源ではマイクロ波のカットオフ密度を超え る高密度なプラズマが生成されていることが確かめられ た。な㧈，すでに図 5 および図 6 に示したように，放電の 形態は，マイクロ波電力が $100 \sim 200 \mathrm{~W}$ の場合に ECR 励 起から表面波励起プラズマに遷移した。このときのプラズ マ密度は, 図 7 から分かるように $N_{e} \sim 1 \times 10^{11} \mathrm{~cm}^{-3}$ であ る。

〈3・4〉ガス圧力依存性図9 図 12 にマイクロ波電 力を $300 \mathrm{~W}$ 一定とし，ガス圧力を 0.2 から $10 \mathrm{mTorr}$ で変化させた際のプラズマ特性の変化を示す。図 9 と図 10 では，それぞれガス圧力をパラメータ $\left(P_{0}=0.5 ， 2 ， 5\right.$ mTorr）として，処理室底面の石英空から見たプラズマ 発光の写真と $\mathrm{Ar}(750.3 \mathrm{~nm})$ の発光強度の径方向分布で

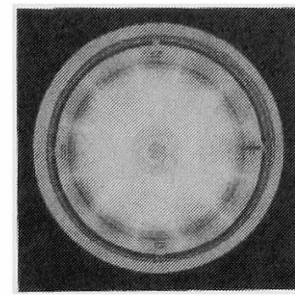

(a) $0.5 \mathrm{mTorr}$

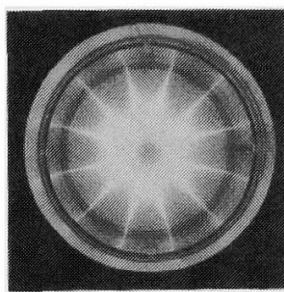

(b) 2 mTorr

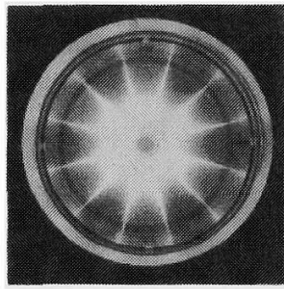

(c) 5 mTorr

図 9 プラズマ発光分布（ガス圧力依存性）

Fig. 9. Bottom views of the discharge for different Ar gas pressures $P_{0}$ at $P_{\mathrm{in}}=300 \mathrm{~W}$; (a) $P_{0}=0.5$ mTorr; (b ) $P_{0}=2 \mathrm{mTorr}$; and (c ) $P_{0}=5 \mathrm{mTorr}$.

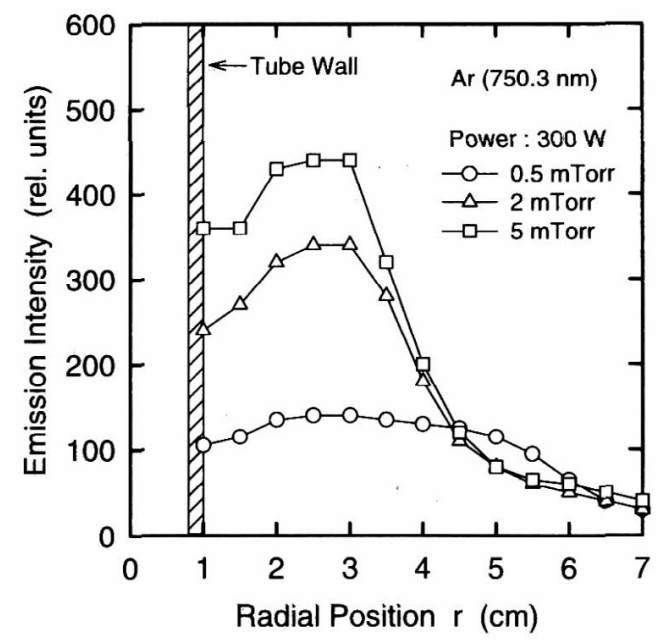

図 $10 \mathrm{Ar}$ 発光強度の径方向分布（ガス圧力 依存性)

Fig. 10. Radial distributions of the $750.3 \mathrm{~nm} \mathrm{Ar}$ emission intensity for different $\mathrm{Ar}$ gas pressures $P_{0}$ at $P_{\mathrm{in}}=300 \mathrm{~W}$.

ある。更に図 11 に, プローブ先端位置をプラズマ生成室 の中心 $(r=0)$ に固定し, プラズマ密度 $\left(N_{e}\right)$ と電子温 度 $\left(T_{e}\right)$ を調べた結果を示す。

図 9 と図 10 亿示されるように, 圧力 0.5 mTorr の場合 にはプラズマ発光や $\mathrm{Ar}$ の発光強度は径方向にほぼ一様で あるが，圧力が 2 および $5 \mathrm{~m}$ Torr の場合には石英チュー 

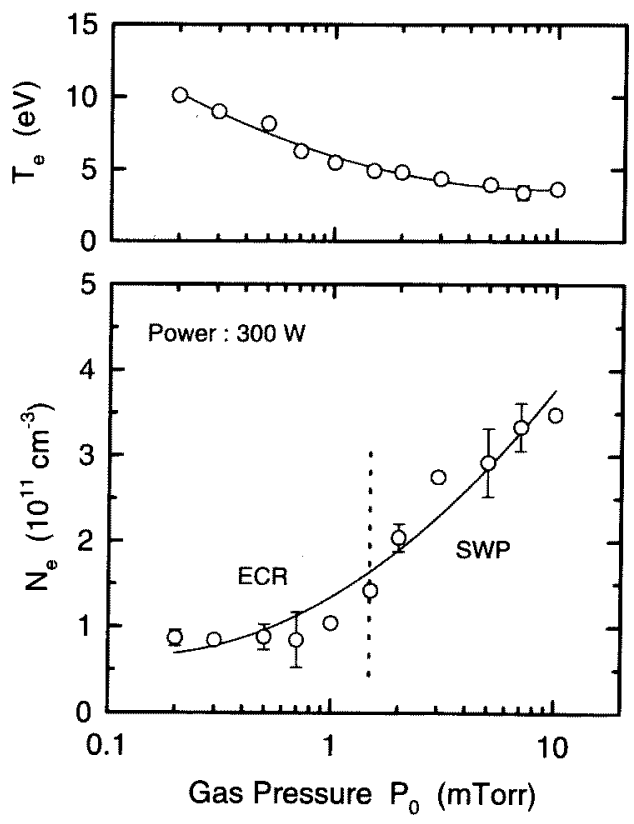

図 11 プラズマ密度 $\left(N_{e}\right)$ および電子温度

$\left(T_{e}\right)$ のガス圧力依存性

Fig. 11. Plasma density $N_{e}$ and electron temperature $T_{e}$ as a function of $\mathrm{Ar}$ gas pressure $P_{0}$ at $P_{\mathrm{ln}}=$ $300 \mathrm{~W}$.

ブの付近 $(r \leqq 3 \mathrm{~cm})$ で非常に強くなっている。このよう な発光分布の変化は, ガス圧力が約 $1.5 \mathrm{mT}$ Torr の場合に 起こり,このときのプラズマ密度は, 図 11 から分かるよ うに $N_{e} \sim 1 \times 10^{11} \mathrm{~cm}^{-3}$ である。この值は，すでに図 5〜図 7 で示したガス圧力を 2 mTorr に固定してマイクロ波電 力を変化させた際に放電形態が遷移するときのプラズマ密 度と一致している。また，ガス圧力を 0.2 から $10 \mathrm{mTorr}$ まで増加させると, 図 11 に示されるように, プラズマ密 度は $N_{e} \approx 8 \times 10^{10}$ から $3.5 \times 10^{11} \mathrm{~cm}^{-3}$ まで単調に増加し, 逆に電子温度は $T_{e} \approx 10$ から $3 \mathrm{eV}$ まで減少する。ここで 得られた最大プラズマ密度 $\left(N_{e} \approx 3.5 \times 10^{11} \mathrm{~cm}^{-3}\right)$ は, マ イクロ波のカットオフ密度の約 5 倍の值である。

図 12 に, プローブ測定と同じ軸方向位置に抬ける径方 向に積分された $\mathrm{Ar}(750.3 \mathrm{~nm})$ と $\mathrm{Ar}^{+}(488.0 \mathrm{~nm})$ の発 光強度のガス压力依存性を示す。ガス圧力を増加させる と, $\operatorname{Ar}(750.3 \mathrm{~nm})$ の発光強度は初め増加し, 圧力が 3 mTorr の場合に最大を示し, その後減少する。また, $\mathrm{Ar}^{+}(488.0 \mathrm{~nm})$ の発光強度は, 圧力範囲 $0.2 \sim 3 \mathrm{mTorr}$ でほほ一定であるが， $3 \mathrm{mT}$ Torr 以上では減少する。これ らの結果は, 図 11 に示したように, ガス圧力の増加に伴 いプラズマ密度は増加するものの電子温度が減少し, その 結果 $\mathrm{Ar} や \mathrm{Ar}^{+}$の発光励起定数 $\left(k_{\mathrm{Ar}} や k_{\mathrm{Ar}}\right)$ が大きく低 下したためであると考えられる。

以上の結果より，マイクロ波電力あるいはガス圧力を変 化させた際に，プラズマ密度が $N_{e} \sim 1 \times 10^{11} \mathrm{~cm}^{-3}$ 以上にな ると放電の形態が $\mathrm{ECR}$ 励起から表面波励起に遷移したと 言える。周波数 $2.45 \mathrm{GHz}$ のマイクロ波に对するカットオ

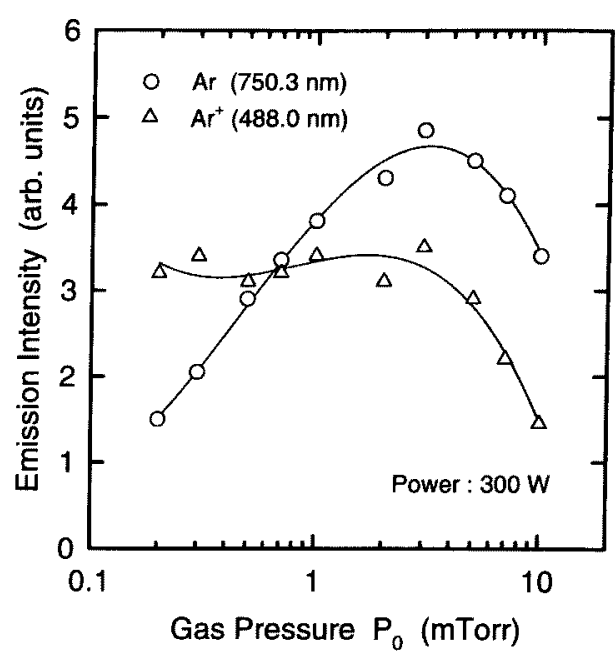

図 $12 \mathrm{Ar}$ 抢よび $\mathrm{Ar}^{+}$発光強度のガス圧力依存性 Fig. 12. Radially integrated intensities of the 750.3 $\mathrm{nm} \mathrm{Ar}$ and $488.0 \mathrm{~nm} \mathrm{Ar}{ }^{+}$emissions as a function of Ar gas pressure $P_{0}$ at $P_{\mathrm{n}}=300 \mathrm{~W}$.

フ密度は $N_{c} \sim 7 \times 10^{10} \mathrm{~cm}^{-3}$ であるが，プローブ法の測定誤 差を考虑すると，この放電形態の遷移はカットオフ密度に 対応すると言える。本方式では，プラズマへのマイクロ波 の入射が無磁場領域で行っているために，カットオフ密度 以下の低密度プラズマにおいては，マイクロ波は体積波と して壁近傍に形成されているECR 領域にまで伝搬するこ とが可能である。一方，カットオフ密度以上の高密度プラ ズマにおいては，マイクロ波は入射・伝搬することができ ず，マイクロ波アンテナの石英チュープとプラズマとの境 界に沿って表面波として伝搬するようになる。こうして， カットオフ密度を境に, 低密度状態では ECR 励起により 主にプラズマが生成され，高密度状態になると表面波励起 によりプラズマ生成が行われると考えられる。

〈3.5〉 マイクロ波電場測定次に, プラズマ中のマ イクロ波電場を測定した結果を示す。図 13 は，マイクロ 波電力が $300 \mathrm{~W}$ ，ガス圧力が $0.5 \mathrm{mT}$ orr と $2 \mathrm{mT}$ Torr の場 合のマイクロ波電場強度の径方向分布である。プラズマ密 度の測定結果（図11）と得られたプラズマの発光分布 (図 9 と図 10) より，ガス圧力が $0.5 \mathrm{mT}$ orr の場合には 低密度 $\left(N_{e} \approx 8 \times 10^{10} \mathrm{~cm}^{-3}\right)$ の $\mathrm{ECR}$ プラズマが, 圧力が 2 mTorr の場合には高密度 $\left(N_{e} \approx 2 \times 10^{11} \mathrm{~cm}^{-3}\right)$ な表面波励 起プラズマがそれぞれ生成されている。压力が 0.5 $\mathrm{mT}$ orr の低密度プラズマでは，マイクロ波の電場強度は 石英チューブから遠ざかるにつれて徐々に滅少している が, 圧力が $2 \mathrm{mTorr}$ の高密度プラズマの場合では, プラ ズマ中の電場強度が著しく小さくなっていることが分か る。これらの結果から, 高密度 $\left(N_{e} \gtrsim 10^{11} \mathrm{~cm}^{-3}\right)$ プラズ マにおいては，マイクロ波は，もはやプラズマ中を伝搬で きず，表面波として石英チューブとプラズマとの境界に浴 ってのみ伝搬していることが確かめられた。

〈3・6〉 プラズマ均一性 最後に, 代表的な生成され 


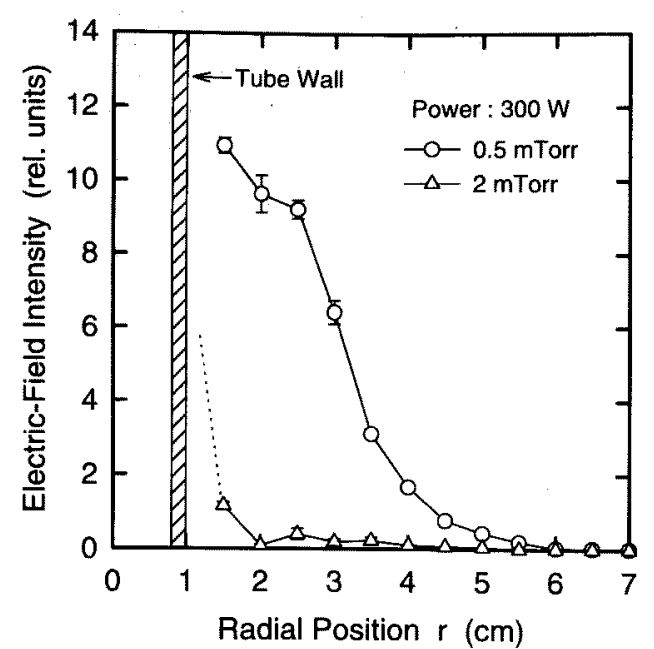

図 13 マイクロ波電場強度の径方向分布

Fig. 13. Radial distributions of the microwave electric-field intensity in plasmas for different $\mathrm{Ar}$ gas pressures $P_{0}=0.5$ and $2 \mathrm{~m}$ Torr at $P_{\mathrm{in}}=300 \mathrm{~W}$.
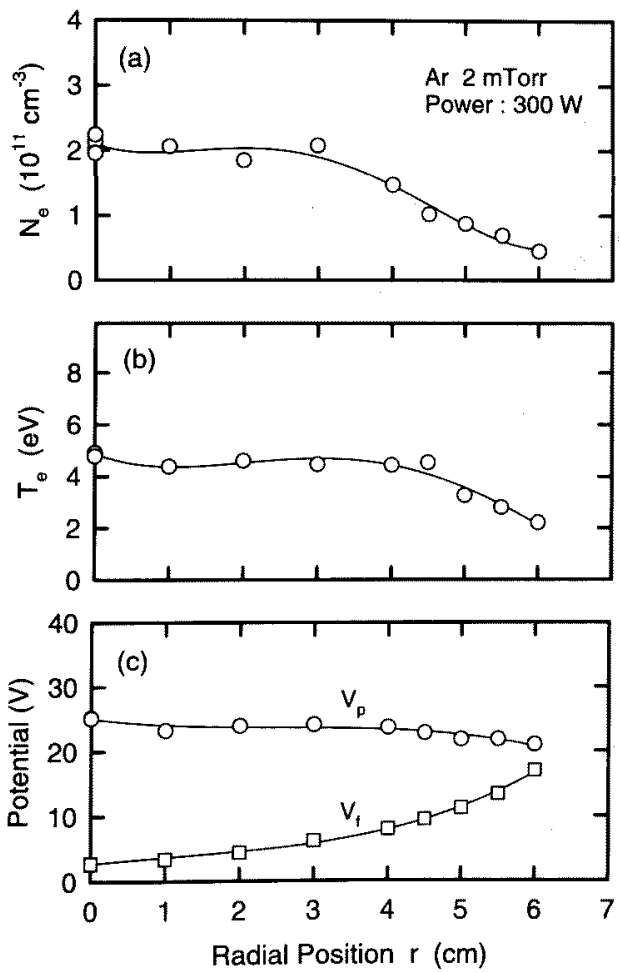

図 14 プラズマパラメータの径方向分布

Fig. 14. Typical radial distributions of (a) the plasma density $N_{e}$, (b) electron temperature $T_{e}$, and (c) plasma $V_{p}$ and floating $V_{f}$ potentials at $P_{0}$ $=2 \mathrm{~m}$ Torr and $P_{\mathrm{in}}=300 \mathrm{~W}$.

た表面波プラズマとして，ガス圧力 $2 \mathrm{mTorr,} \mathrm{マイクロ}$ 波電力 $300 \mathrm{~W}$ の場合のプラズマパラメータ（プラズマ密 度 $N_{e}$, 電子温度 $T_{e}$, プラズマ $V_{p}$ および浮遊 $V_{f}$ 電位) の径方向分布を図 14 に示す。なお，すでに述べたように， プローブの軸方向位置は石英チューブ端の約 $2 \mathrm{~cm}$ 下流で
ある。これらの図から分かるように，プラズマ生成室の中 央部に直径約 $6 \mathrm{~cm}$ の範囲において均一なプラズマが生成 されている。このプラズマ領域はマルチカスプ磁場の無磁 場領域にほほ対応している。また，電子温度 $T_{e}$ やプラズ マ電位と浮遊電位との電位差 $V_{p}-V_{f}$ は, プラズマ生成室 の中心 $(r=0)$ で最大を示し，生成室の内壁に近づくに つれて単調に減少している。このことからも, 高密度 $\left(N_{e} \gtrsim 10^{11} \mathrm{~cm}^{-3}\right)$ プラズマの場合には，プラズマ中に電子 を加熱するマイクロ波電場はほとんどなく，生成室の中心 軸上に設置された石英チューブ近傍でのみ存在するマイク 口波電場により電子が加熱されていると考えられる。すな わち，表面波励起によりプラズマが生成されていると言え る。

\section{4. 結 論}

軸対称モードの表面波励起とマルチカスプ磁場によるプ ラズマ閉じ込めを組み合わせた新しい表面波プラズマ源の 開発を行っている。本方式では，マルチカスプ磁場の無磁 場領域に設置された石英チューブの近傍で表面波励起によ りプラズマの生成が行われるため, 発生したプラズマには $\operatorname{grad}-B$ や湾曲ドリフト運動が起こらず，マルチカスプ磁 場の閉じ込め効果が強く働く。プローブ計測, 発光分光, マイクロ波電場測定によるプラズマ診断を行った結果，放 電の開始は ECRにより引き起こされ，プラズマの密度が マイクロ波のカットオフ密度 $\left(N_{c} \sim 7 \times 10^{10} \mathrm{~cm}^{-3}\right)$ を超え ると，表面波励起により石英チューブの近傍で高密度プラ ズマが生成・維持されることが分かった。本方式では，10 mTorr 以下の低ガス圧力下でもプラズマ密度 $N_{e} \gtrsim 10^{11}$ $\mathrm{cm}^{-3}$, 電子温度 $T_{e} \sim 5 \mathrm{eV}$ の高密度プラズマが生成され る。

(平成 10 年 1 月 30 日受付, 同 10 年 6 月 9 日再受付)

\section{文献}

(1) M. A. Lieberman \& A. J. Lichtenberg: Principles of Plasma Discharges and Materials Processing, (1994) WileyInterscience, New York

(2) H. Tsuboi, M. Itoh, M. Tanabe, T. Hayashi \& T. Uchida : "Usefulness of Magnetic Neutral Loop Discharge Plasma in Plasma Processing", Jpn.J. Appl. Phys., 34, 2476 2481 (1995)

(3) S. Samukawa, Y. Nakagawa, T. Tsukada, H. Ueyama \& K. Shinohara: "New Ultra-High-Frequency Plasma Source for Large-Scale Etching Processes", ibid., 34, 6805 6808 (1995)

(4) M. Moisan \& Z.Zakrzewski: "Plasma Sources Based on the Propagation of Electromagnetic Surface Waves", J. Phys. $D$ : Appl. Phys., 24, 1025 1048 (1991)

(5) K. Komachi: "Affecting Factors on Surface-Wave-Produced Plasma", J. Vac. Sci. Technol., A11, 164 167 (1993)

(6) T. Kimura, Y. Yoshida \& S. Mizuguchi: "Generation of a Surface-Wave-Enhanced Plasma Using Coaxial-Type OpenEnded Dielectric Cavity", Jpn.J. Appl. Phys., 34, L 1076 L 1078 (1995)

(7) F. Werner, D. Korzec \& J. Engemann: "Surface Wave Operation Mode of the Slot Antenna Microwave Plasma Source SLAN", J. Vac. Sci. Technol., A14, 3065 3070 (1996)

(8) M. Nagatsu, G. Xu, M. Yamage, M. Kanoh \& H. Sugai : "Optical Emission and Microwave Field Intensity Measurements in Surface Wave-Excited Planar Plasma", Jpn. J. Appl. 
Phys., 35, L 341 L 344 (1996)

(9) M. Nagatsu, G. Xu, I. Ghanashev, M. Kanoh \& H. Sugai : "Mode Identification of Surface Waves Excited in a Planar Microwave Discharge", Plasma Sources Sci. Technol., 6 , 427 434 (1997)

(10) R. Limpaecher \& K. R. MacKenzie: “Magnetic Multipole Containment of Large Uniform Collisionless Quiescent Plasmas", Rev. Sci. Instrum., 44, 726 731 (1973)

(11) K. N. Leung, T. K. Samec \& A. Lamm: "Optimization of Permanent Magnet Plasma Confinement", Phys. Lett., 51A, 490 492 (1975)

(12) W. L. Stirling, P. M. Ryan, C. C. Tsai \& K. N. Leng: "Magnetic Multipole Line-Cusp Plasma Generator for Neutral Beam Injectors", Rev. Sci. Instrum., 50, 102 108 (1979)

(13) H. Goede: " $30-$ cm Electron Cyclotron Plasma Generator", $J$. Spacecraft, 24, 437 443 (1987)

(14) M. Pichot, A. Durandet, J. Pelletier, Y. Arnal \& L. Vallier : "Microwave Multipolar Plasmas Excited by Distributed Electron Cyclotron Resonance: Concept and Performance", Rev. Sci. Instrum., 59, 1072 1075 (1988)

(15) G. Neumann \& K.-H. Kretschmer: "Characterization of a New Electron Cyclotron Resonance Source Working with Permanent Magnets", J. Vac. Sci. Technol., B9, 334 338 (1991)

(16) T. Namura, I. Arikata, O. Fukumasa, M. Kubo \& R. Itatani : "Effects of Permanent Magnet Arrangements and Antenna Locations on the Generation of Multicusp Electron Cyclotron Resonance Plasma", Rev. Sci. Instrum., 63, 21 30 (1992)

(17) A. Hatta, M. Kubo, Y. Yasaka \& R. Itatani : "Performance of Electron Cyclotron Resonance Plasma Produced by a New Microwave Launching System in a Multicusp Magnetic Field with Permanent Magnets", Jpn. J. Appl. Phys., 31, 1473 1479 (1992)

(18) M. Tuda, K. Ono, M. Taki \& K. Namba: "Multicusp Electron-Cyclotron-Resonance Plasma Source Working with Microwaves Radially Injected through an Annular Slit", ibid., 33, 1530 1537 (1994)

(19) L. S. Napoli \& G. A. Swartz: "Wave Propagation in a Tubular Plasma”, Phys. Fluids, 6, 918 924 (1963)

(20) S. F. Paik, R. J. Briggs \& J. M. Osepchuk: "Experiments on Surface Wave Propagation along Annular Plasma Columns", J. Appl. Phys., 37, 2475 2483 (1966)

(21) S. Ikezawa, Y. Shiraki, J. Inaguma, Y. Mikawa, F. Mutsuga, M. Fujii, R. Miyano, K. Baba, K. Kida, A. Nishiwaki, Y. Okamoto, S. Nonaka, M. Kando \& M. Nagatsu: "Field Strength in Plasma Produced by Coaxially Symmetric Sur. face Wave in VHF Band", Proc. 13 th Int. Symp. Plasma Chem., Beijing, 1997, Peking Univ., Beijing, p. 426 431 (1997)

$\begin{array}{lll}\& \infty & \& \infty\end{array}$

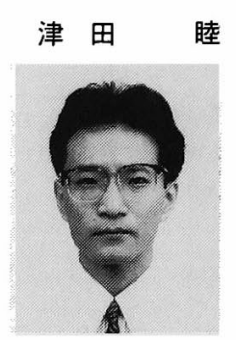

（非会員） 1962 年 1 月 23 日生。1987 年 3 月大 阪府立大学大学院工学研究科修士課程数理工学 専攻修了。同年三菱電機(株)入社。プラズマエ ッチング,クリーニングなどの半導体プロセ ス・装置の研究開発に従事。現在, 先端技術総 合研究所に所属。応用物理学会, 日本物理学会, American Vacuum Society 会員。

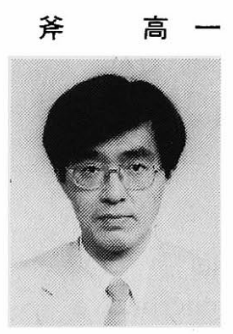

（正員） 1951 年 3 月 27 日生。 1978 年 3 月京都 大学大学院工学研究科博士課程航空工学専攻修 了。1982 年三菱電機 (株) 入社。プラズマ・レー ザ機器にかかわる研究開発を経て, エッチング, $\mathrm{CVD}$, クリーニングなどの半導体プロセス・装 置の研究開発に従事。現在, 先端技術統合研究 所に所属。工学博士。応用物理学会, プラス マ・核総合学会, 日本物理学会, American

Physical Society 会員。

土橋祐亮 (正員) 1963 年 1 月 25 日生。1986 年 3 月福岡

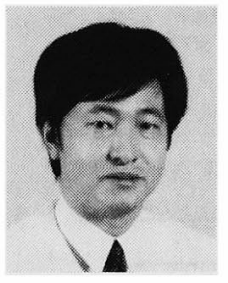
大学機械工学科卒業。1 1988 年 3 月九州大学大学 院総合理工学研究科修士課程エネルギー变換工 学専攻修了。同年三菱電機(株) 入社。主として, プラズマを利用した半導体ウェーハプロセス装 置開発に従事。現在, 半導体基盤技術統括部装 置技術部に所属。応用物理学会, 日本機械学会 会員。

花 崎

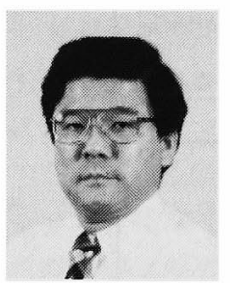

稔（正員） 1953 年 2 月 16 日生。1977年 3 月早稲 田大学大学院理工学研究科修士課程高電圧工学 専攻修了。同年三菱電機(株) 入社。中央研究所 にて変圧器絶縁などの研究開発を経て, エッチ ングなどのウェーハプロセス装置開発などに従 事。現在, 半導体基盤技術統括部装置技術部に 所属。応用物理学会会員。
米 村 俊 㜠

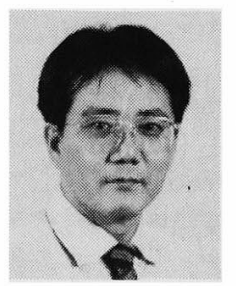

(非会員) 1953 年 1 月 7 日生。1975 年 3 月東京 電機大学精密機械工学科卒業。同年三菱電機 (株)入社。半導体アセンブリ装置開発を経て, 半導体ウェーハプロセス装置開発に従事。現在, 半導体基盤技術統括部装置技術部门エ八装置技 術課長。 